McGill Law Journal

Revue de droit de McGill

\title{
R.W. Kostal, A Jurisprudence of Power: Victorian Empire and the Rule of Law (Oxford and New York: Oxford University \\ Press, 2008), pp. xiii, 529
}

\section{Mark Antaki}

Volume 55, numéro 2, july 2010

URI : https://id.erudit.org/iderudit/045093ar

DOI : https://doi.org/10.7202/045093ar

Aller au sommaire du numéro

Éditeur(s)

McGill Law Journal / Revue de droit de McGill

ISSN

0024-9041 (imprimé)

1920-6356 (numérique)

Découvrir la revue

Citer ce compte rendu

Antaki, M. (2010). Compte rendu de [R.W. Kostal, A Jurisprudence of Power: Victorian Empire and the Rule of Law (Oxford and New York: Oxford University Press, 2008), pp. xiii, 529]. McGill Law Journal / Revue de droit de McGill, 55(2), 371-374. https://doi.org/10.7202/045093ar d'utilisation que vous pouvez consulter en ligne.

https://apropos.erudit.org/fr/usagers/politique-dutilisation/ 
what degree, with the passage of time, will the contributing essayists be obliged by the editor to partially modify their views? And will any essays in the first edition have become completely redundant?

Again, to the readers of Legal Issues and, in this case, to the essayists as well, bon voyage et bonne lecture.

William Tetley C.M., Q.C.

\begin{abstract}
BOOK NOTE
R.W. Kostal, A Jurisprudence of Power: Victorian Empire and the Rule of Law (Oxford and New York: Oxford University Press, 2008), pp. xiii, 529.
\end{abstract}

First published in hardback in 2005, reprinted in 2006, and first published in paperback in 2008, R.W. Kostal's A Jurisprudence of Power: Victorian Empire and the Rule of Law 18 is usefully contrasted with other recent works on the rule of law such as Brian Z. Tamanaha's On the Rule of Law: History, Politics, Theory. ${ }^{19}$ As opposed to covering thousands of years as well as the politics and theory of the rule of law in 180 pages, Kostal, a historian and professor of law at the University of Western Ontario, and author of Law and English Railway Capitalism, 1825-1875, ${ }^{20}$ spends 529 pages (comprising an introduction, seven chapters, an epilogue, a conclusion, and an appendix) focusing on one historical episode spanning less than a decade.

A Jurisprudence of Power provides an extensive treatment grounded in primary sources, including journalistic ones, of "the prolonged conflict that arose in England over the suppression of the Morant Bay uprising in Jamaica" in October 1865, when "a crowd of black men and women attacked and burned" a courthouse. ${ }^{21}$ Its suppression involved the proclamation of martial law by then Governor of Jamaica, Edward John Eyre, and the "killing and torturing [of] hundreds of black Jamaicans-that is to say, British subjects." 22 The prolonged conflict that arose in England cen-

18 R.W. Kostal, A Jurisprudence of Power: Victorian Empire and the Rule of Law (Oxford and New York: Oxford University Press, 2008) [A Jurisprudence of Power].

19 Brian Z. Tamanaha, On the Rule of Law: History, Politics, Theory (Cambridge: Cambridge University Press, 2004).

20 R.W. Kostal, Law and English Railway Capitalism, 1825-1875 (Oxford: Clarendon Press, 1994).

21 A Jurisprudence of Power, supra note 1 at 1.

22 Ibid. 
tred on the propriety and legality of the killing and torture. It was tied, in some measure, to conflicting understandings of martial law and of a colonial indemnity act, ${ }^{23}$ but also to a broader concern that "[a] sprawling empire of non-white, non-Christian peoples could not be safely governed within a scrupulous constitutional framework." ${ }^{24}$ The conflict in England was also closely tied to the activities of the Jamaica Committee, a "grand coalition of Christian activists and secular liberals" 25 whose "raison d'être ... was to defend a liberal jurisprudence of power." 26 Their efforts to criminally prosecute Eyre and others brought to the fore the "contradictions thrown up by law and imperialism," ${ }^{27}$ and raised the question of whether there could be "such [a] thing as a liberal empire." ${ }^{8}$ Kostal's pairing of law and liberalism, not at all unusual,29 invites a reading of his work alongside that of Uday Singh Mehta's Liberalism and Empire: A Study in Nineteenth-Century British Liberal Thought. ${ }^{30}$ Mehta's book notably includes a treatment of John Stuart Mill, who became a central actor in the Jamaica Committee and therefore in Kostal's story.

Kostal devotes his efforts to attending to, mapping out, and thematizing the English preoccupation with legality as manifested in, but also as constitutive of, the Jamaica controversy. Throughout his book, Kostal aims "to show how legal ways of seeing and doing were central features of English political discourse and conflict." ${ }_{11} \mathrm{He}$ aims in part to provide a corrective to previous historical accounts of the Jamaica controversy which "failed to apprehend that the Jamaica affair was understood, described, and contested largely in terms of legal language and procedures." 32 Kostal's book narrates and reconstructs one historical episode closely tied to what Judith N. Shklar has famously called legalism, "the ethical attitude that holds moral conduct to be a matter of rule following, and moral relationships to consist of duties and rights determined by

23 Ibid. at 11.

24 Ibid. at 68.

25 Ibid. at 15.

26 Ibid. at 473.

27 Ibid. at $485-86$.

28 Ibid. at 486.

29 With respect to Canadian legal history, see e.g. Robert C. Vipond, Liberty and Community: Canadian Federalism and the Failure of the Constitution (Albany: State University of New York, 1991), (see especially c. 5, "Provincial Autonomy and the Rule of Law" at 113). See also the work of Richard Risk.

30 Uday Singh Mehta, Liberalism and Empire: A Study in Nineteenth-Century British Liberal Thought (Chicago, University of Chicago Press, 1999).

31 A Jurisprudence of Power, supra note 1 at 464.

32 Ibid. at 2. 
rules" 33 and of which "[t]he court of law and the trial according to law are the social paradigms, the perfection, the very epitome." 34

Kostal's twenty-two page introduction sets forth the Morant Bay uprising, its suppression, and the formation of the Jamaica Committee. He ties the uprising at the courthouse to a racist local justice and situates it against British Jamaica's history and constitution, particularly its history of slavery and slave insurrection. He also draws attention to the suppression's most famous victim, a "coloured landowner-politician, George Gordon," 35 who had been a prominent advocate of reforms but of whom it had not been alleged that he "had been directly involved in acts of violence." ${ }^{36}$ Even though he surrendered voluntarily when charged with high treason and sedition, he was removed "from the civilian jurisdiction of Kingston for trial by a military tribunal at Morant Bay." ${ }_{37} \mathrm{He}$ was "[d]enied access to a lawyer, and most other vestiges of civilian criminal justice,"38 and was ultimately sentenced to execution and hanged.

Kostal finds "unremarkable" that "[t]he insecurity of whites had always been the central premiss of public law and planning in the colony" but finds " $[\mathrm{m}]$ ore intriguing" that "Jamaica's colonial officials ... in the face of dire public emergency, were also preoccupied with legality." 39 This preoccupation, Kostal explains, also characterized Eyre's response to the rebellion and his turn to legal advice and to martial law. Nevertheless, "[t]he definition of martial law was one vexed question, the nature of the legal authority to proclaim martial law another." 40 The preoccupation with legality coupled with martial law's unsettled character are inseparable and dominant themes in Kostal's account and reflect the title of his work.

Kostal begins the principal part of his narrative by tracing the transformation of the Jamaica affair into a historical episode of legalism and ends by pointing to some of the limits of this legalism. The first chapter, "The Country of Law': Reconstructing the Morant Bay Uprising in England", shows how "[i]n the space of just more than two weeks," beginning in the first week of November 1865, "the Jamaica affair had been transformed from a narrative about the salvation of Jamaican colonists into a

Judith N. Shklar, Legalism: Law, Morals, and Political Trials (Cambridge, Mass.: Harvard University Press, 1964) at 1.

34 Ibid. at 2.

35 A Jurisprudence of Power, supra note 1 at 13.

36 Ibid. at 14.

37 Ibid.

38 Ibid.

$39 \quad$ Ibid. at 7.

40 Ibid. at 10. 
narrative about the destruction of the English constitution." ${ }_{11}$ The last chapter, "The Most Law-Loving People in the World': The Denouement of the Jamaican Litigation", ends with the following two sentences: "The courtroom, it was commonly thought, was a 'sphere that ought to be free from all disturbance.' The Jamaica affair had done much to dispel this myth." 42

The seven chapters as a whole narrate the Jamaica affair, focusing in particular on the Jamaica Committee's attempts to criminally prosecute Eyre, who became "the living embodiment of the argument for (and against) martial law," 43 for the murder of Gordon. "The paradox of the Jamaica affair," Kostal shows using the Gordon case as an example, "is that it so quickly stopped being about Jamaica and Jamaicans." ${ }^{44}$ In part because of the leadership of John Stuart Mill and in part because of surrounding circumstances, by the end of 1866, the Jamaica affair had turned into "a dispute about the civil liberties of Englishmen at home." 45 It "was no longer about the violence done to a hapless black peasantry. It was now mainly about the violence done to the laws of England." 46 Kostal charts the Committee's attempts to attain "[i]ts single and unwavering goal," "to provide an occasion for a high court judge - an unelected official-to vindicate what was viewed as the country's 'true' constitution." 47 Kostal writes, "More specifically, the Committee wanted to provide an opportunity (in the form of a criminal case) for a high court judge to pronounce that the summary arrest, court martial, and execution of civilians was illegal even when done under the banner of martial law." 48 Ultimately, while "the Jamaica Committee failed to achieve a decisive legal precedent about the law of martial law," it "succeeded in causing the English governing class to confront the contradiction between the love of power and the love of law." 49 The Epilogue turns to civil litigation against Eyre after the Jamaica Committee abandoned the strategy of (private) criminal prosecution.

$41 \quad$ Ibid. at 37.

42 Ibid. at 431.

43 Ibid. at 271.

44 Ibid. at 190.

45 Ibid.

46 Ibid. Compare with Valverde's reading of R. v. Butler ([1992] 1 S.C.R. 452, 89 D.L.R. (4th) 449) in which she highlights the Supreme Court of Canada's transformation of the Canadian Charter itself into "a new potential victim of pornography": Marianna Valverde, Law's Dream of a Common Knowledge (Princeton, Princeton University Press, 2003) at 38.

47 A Jurisprudence of Power, supra note 1 at 372.

48 Ibid.

49 Ibid. at 19. 
In his conclusion, Kostal remarks:

If the legal system had failed to deliver a decisive answer to the contradictions thrown up by law and imperialism, it was because they could not be answered decisively, not, at least by citing legal authorities. The constitutional law of England was not so much a fixed body of precedents as a deep reservoir of public conscience, one roiled by powerful cross-currents.

If it seems obvious that all constitutions, even those that have been arranged systematically, are dynamic and contestable, this point was not obvious to the main protagonists of the Jamaica affair. Even Mill, the enormously erudite leader of the Jamaica Committee, advanced a strangely naive view of constitutional law and interpretation. Throughout the duration of the Jamaica controversy Mill spoke of "great legal and constitutional principles" as if they were rules of arithmetic. ${ }^{50}$

The tendency to see legal and constitutional principles as rules of arithmetic is symptomatic of a legalism that forecloses the possibility of "an approach suitable to law as an historical phenomenon." 51 Kostal's book is an extended invitation to not take for granted the turns to rules, lawyers, and courts. Kostal invites us to see these turns as political ones tied to historically situated ways of thinking and doing. As the McGill Law Journal's special issue on the fiftieth anniversary of Roncarelli $v$. Duplessis should remind us, ${ }^{52}$ one of the dangers of abstractly celebrating the rule of law and its various moments of triumph is the neglect of our history.

Mark Antaki

$50 \quad$ Ibid. at $485-86$.

51 Shklar, supra note 16 at 3.

52 This special issue is forthcoming in (2010) 55 McGill L.J. 